\author{
Marquette University \\ e-Publications@Marquette
}

$1-2011$

\title{
Environmental Influences on Young Adult Weight Gain: Evidence from a Natural Experiment
}

Kandice A. Kapinos

University of Michigan - Ann Arbor

Olga Yakusheva

Marquette University, olga.yakusheva@marquette.edu

Follow this and additional works at: https://epublications.marquette.edu/econ_fac

Part of the Economics Commons

\section{Recommended Citation}

Kapinos, Kandice A. and Yakusheva, Olga, "Environmental Influences on Young Adult Weight Gain:

Evidence from a Natural Experiment" (2011). Economics Faculty Research and Publications. 26.

https://epublications.marquette.edu/econ_fac/26 


\title{
Environmental Influences on Young Adult Weight Gain: Evidence from a Natural Experiment
}

\author{
Kandice A. Kapinos \\ Institute for Social Research, University of Michigan \\ Ann Arbor, MI \\ Olga Yakusheva \\ Department of Economics, Marquette University \\ Milwaukee, WI
}

\begin{abstract}
Objectives: This study investigated the importance of environmental influences in explaining weight gain and related behaviors among freshman college students.

Methods: We exploited a natural experiment that takes place on most college campuses in the United States - randomized dormitory assignments. We estimated the effects of living in dormitories with varying physical environment characteristics on weight gain and related behaviors (daily number of meals and snacks, weekly frequency of exercise) among randomly assigned freshman students.

Results: We found strong evidence linking weight and related behaviors to individual dormitories, as well as to specific characteristics of the dormitories. On average, students assigned to dormitories with on-site dining halls gained more weight and exhibited more behaviors consistent with weight gain during the freshman year as compared with students not assigned to such

dormitories. Females in such dormitories weighed $.85 \mathrm{~kg}(p=.03)$ more and exercised $1.43(p<.01)$ times fewer; males consumed $.22(p=.02)$ more meals and .38 ( $p=.01)$ more snacks. For female students, closer proximity of the dormitory to a campus gym led to more frequent exercise $(.54, p$ $=.03)$, whereas living closer to central campus reduced exercise $(-.97, p$ $=.01)$.


NOT THE PUBLISHED VERSION; this is the author's final, peer-reviewed manuscript. The published version may be accessed by following the link in the citation at the bottom of the page.

Conclusions: Using a natural experiment to deal with the potential endogeneity of the living environment, this study found that the physical environment affects both students' weight changes and weight-related behaviors.

Keywords: Natural experiment; Adolescent obesity; Physical environment

The increase in the prevalence of obesity in the United States in recent decades has resulted in considerable attention by public health and policy initiatives, the media, medical practitioners, and researchers alike. Numerous studies have investigated both the antecedents and consequences of being overweight or obese. The finding that body weight depends not only on biological factors, but also on environmental factors, implies that interventions that mitigate environmental influences are important in policies aimed at addressing this growing problem ${ }^{1,2,3}$.

Obesity research focusing on the physical environment has investigated the role of the proximity, density, selection of healthy foods and eating facilities, and aspects of the built environment, such as "walkability," access to exercise facilities, parks, trails, urbanizaion, and crime ${ }^{4,5,6,7}$. Much of this work has found significant associations between characteristics of the physical environment and obesity. Living near supermarkets yields greater consumption of fruits and vegetables ${ }^{4}$, whereas individuals who live in areas with higher concentrations of fast food restaurants tend to weigh more on average $\mathrm{e}^{8,9,10}$. Individuals who have greater access to parks, gyms, or walking/jogging trails are more likely to engage in physical activity ${ }^{6}$ and, not surprisingly, individuals who walk more and spend less time driving tend to have lower obesity rates ${ }^{5}$. A recent meta-analysis concluded that access to fast food and recreational facilities is consistently linked to weight-related behaviors and outcomes in adults ${ }^{3}$.

However, all of this evidence relies on analyses that do not deal with the likely possibility that individuals choose to work and live in environments best suited for their lifestyles, and that restaurant and food store retailers, as well as fitness and recreation facilities, choose to locate their businesses in places where demand for such amenities is likely to be high. This reverse causality can lead to unreliable conclusions about the role of physical environment as a policy lever in

[Citation: Journal/Monograph Title, Vol. XX, No. X (yyyy): pg. XX-XX. DOI. This article is @ [Publisher's Name] and permission has been granted for this version to appear in e-Publications@Marquette. [Publisher] does not grant permission for this article to be further copied/distributed or hosted elsewhere without the express permission from [Publisher].] 
promoting healthy lifestyles and reducing obesity. In this study, we exploited the fact that many first-year college students are required to live in a randomly assigned dormitory and not all dormitories offer the same physical environment. This allowed us to indentify more convincingly the causal link between physical environment and weight.

Between 1988 and 2006, obesity prevalence in young adults, aged 18-29, increased 96\% -the largest percent increase for all age groups ${ }^{11,12,13}$. Although recent research suggests that the average amount of weight gained by first-year college students-the so-called "Freshman 15 "-is more likely to be around 2.5 to 6 pounds, others have argued that college freshmen gain weight at a greater rate than do others in the general population, and behaviors at this age likely influence long-term behaviors ${ }^{14,15,16,17,18,19,20,21,22,23}$. In fact, the Healthy People 2010 program urges policymakers to seize the "window of opportunity" to encourage children and young adults to establish good eating and exercise behaviors now so that they might carry over into adulthood $^{24}$, whereas college campuses have been identified as a particularly important target for weight-related policy interventions ${ }^{25}$.

The specific aims of this study were to: (1) examine whether there were differences in weight-related behaviors and weight gain during the freshman year among students randomly assigned to different campus dormitories; and (2) link the differences in weightrelated behaviors and weight gain to three specific dormitory characteristics: the presence of an on-site cafeteria, the distance to central campus, and the distance to the gym.

\section{Methods}

\section{Sampling and data collection}

We obtained informed consent from all participants and all aspects of this study, including the survey instrument, were reviewed and approved by the university's Institutional Review Board. We solicited participation in the survey from all first-year students aged $\geq 18$ years through university e-mail during a 10 -day period starting in the second week of classes in the fall of 2008 (baseline $n=1,057$, $54 \%$ response rate) and immediately after the final examination week 
in the spring of 2009 ( $n=600,43 \%$ loss to attrition). In both the fall and spring, we included participants in a lottery, with 124 cash prizes ranging from $\$ 5$ to $\$ 100$. After excluding students who lived off campus ( $n=63$ ), we obtained our initial sample of 537 students ( 344 females and 193 males). We further restricted this sample as described in the next section.

To test for selection in nonresponse, we used the method of comparing early respondents with late respondents ${ }^{26}$, by operationally defining late respondents on the basis of successive waves of responses generated by the initial solicitation e-mail and two subsequent reminder e-mails ${ }^{27}$. We found that conditional on the gender, there were no significant differences between early and late respondents in any of the variables used in the study. Furthermore, all findings reported are robust to controlling for the "days to respond" variable in the analyses ${ }^{27}$.

\section{Dormitory characteristics and the assignment process}

The campus in our study is a walking campus (i.e., there is no campus public transportation and the city public transit system does not offer useful routes for student use for travel in or around campus) situated on approximately 90 acres of land in an urban setting. There are seven freshman dormitories on campus, and they differ by location and amenities (Figure 1). The majority of them are co-ed, except for dormitory 6 (male only) and dormitory 3 (female only). Four of the seven dormitories $(3,4,5$, and 7$)$ have on-site dining facilities that offer buffet-style breakfast, lunch, and dinner. Approximately $65 \%$ of the students in our full sample lived in a dormitory with an on-site dining hall, although this varied considerably by gender (Table 1 ). Ninety-eight percent of the students in our sample purchased some type of university meal plan that entitled them to use any of the campus dining facilities. The university contracts with one of the worldwide leaders in providing campus food services. All dining halls offer a wide range of nutritious menu options in an all-you-can-eat format. They offer continuous service from morning until night and do not close between meals. The menu and nutritional content is available online, along with a nutritional calculator for most foods. 
NOT THE PUBLISHED VERSION; this is the author's final, peer-reviewed manuscript. The published version may be accessed by following the link in the citation at the bottom of the page.

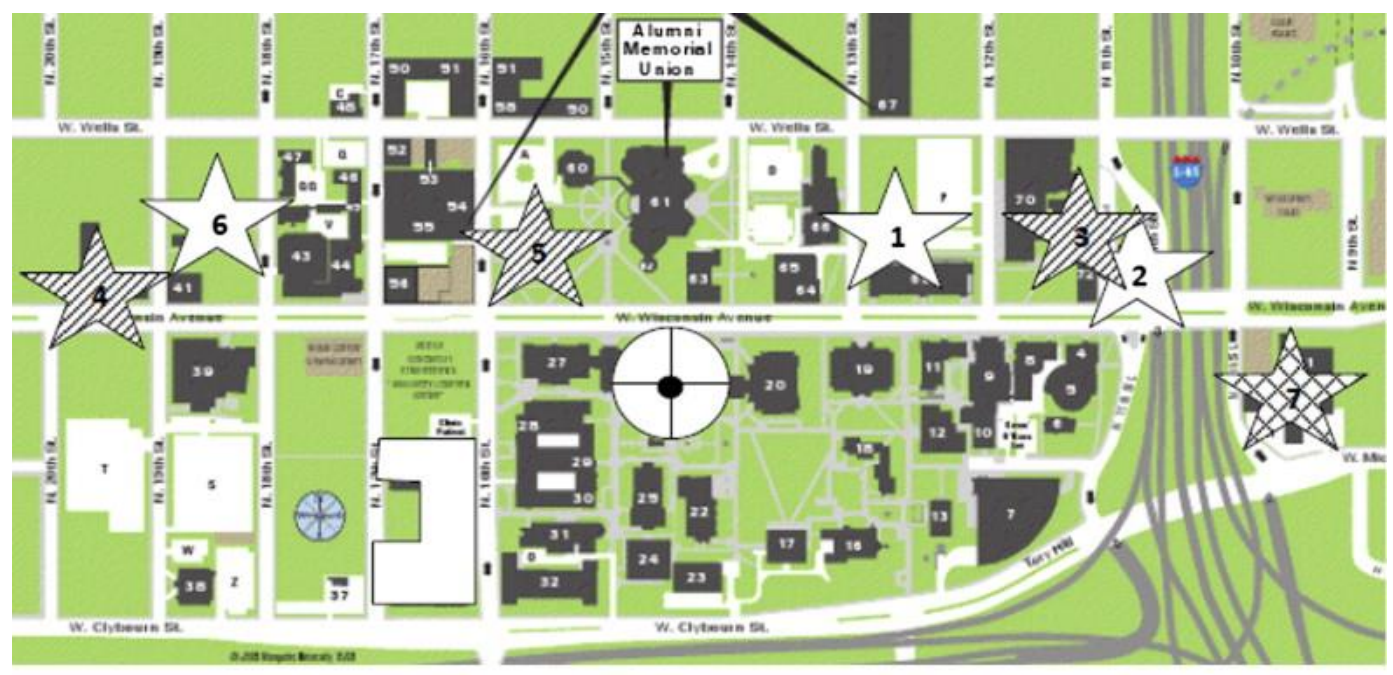

Legend: $\hat{W}$ Dormitory $(1,2,6)$;

Dormitory with on-site dining $(3,5,4)$;

Dormitory with on-site dining and on-site gym (7)

5 Main gym

Denter of campus, main library and study center

Figure 1. Campus map.

Table 1. Descriptive statistics by gender

Baseline Follow-up Difference $p$-value

Males $(n=144)$

Weight $(\mathrm{kg})$

77.89

78.55

.66

.063

Exercise frequency per week

5.52

4.34

$-1.18$

$<.001$

Meals per day

3.04

2.96

$-.08$

Snacks per day

2.41

1.8

.61

$<.001$

Lives in dorm with dining hall (\%)

31.25 (46.51)

Proximity to gym

$.21(.10)$

Proximity to central campus

$.30(.09)$

Females $(n=244)$

Weight $(\mathrm{kg})$

62.63

63.86

1.23

$<.001$

Exercise frequency per week

4.7

3.53

$-1.17$

$<.001$

Meals per day

2.88

2.61

$-.26$

$<.001$

Snacks per day

2.33

1.88

$-.45$

$<.001$

Lives in dorm with dining hall (\%)

$77.05(42.14)$

Proximity to gym

$.17(.08)$

Proximity to central campus

$.24(.04)$

[Citation: Journal/Monograph Title, Vol. XX, No. X (yyyy): pg. XX-XX. DOI. This article is @ [Publisher's Name] and permission has been granted for this version to appear in e-Publications@Marquette. [Publisher] does not grant permission for this article to be further copied/distributed or hosted elsewhere without the express permission from [Publisher].] 
Note: Standard deviations in parentheses. All proximity measures are in miles.

There is considerable variance across dormitories regarding the proximity to central campus, with the closest dormitory located .17 miles away and the farthest being .43 miles away. To put this in context, students living in remote dormitories may have to walk as much as half a mile more per day than students living in centrally located dormitories. The campus has two gymnasiums: a smaller recently renovated gym located in dormitory 7 located .39 miles away from central campus, and a larger stand-alone general-purpose gym located .28 miles away from central campus and .65 miles away from the other gym. Both gymnasiums offer state-of-the-art weight and aerobic training rooms and lap swimming pools. The stand-alone gym also includes a large indoor space for team and racquet sports.

All freshmen were required to live in campus dormitories (exceptions were made only for students with special needs). In the spring before enrollment, the Office of Residence Life (ORL) at our study site required all incoming freshman students to submit a housing application form with instructions to identify the desired room type; the first, second, third, and fourth dormitory preferences; and a roommate if desired. After the ORL verified receipt of all applications, computerized housing assignment software assigned applicants a random priority number. The priority number did not depend on the date of submitting the application or any other criteria. The housing software matched students on the basis of application criteria (roommate, room type, and hall) with available spaces. Roommate preferences took priority over dormitory preferences. According to the $\mathrm{ORL},<1 \%$ of freshman students switched dormitories during the study period but no dormitory switches were reported in our sample.

Over $70 \%$ of males and females in the sample requested dormitory 1 or 2 as their first choice, but only $22 \%$ of males and $16 \%$ of females were actually placed in these two dormitories. Of the female students who requested dormitory 1 or 2 , but were randomly placed in a different dormitory, most were placed in dormitories 3 (36\%) and 5 (36\%), although these two dormitories were relatively low (jointly accounting for only $20 \%$ ) on the request list. Similarly, most male students who requested dormitory 1 and 2 but because of random chance were not assigned to these dormitories were placed in 
dormitory $5(30 \%)$ and $6(38 \%)$, both of which were infrequently requested ( $13 \%$ and $<4 \%$, respectively). Almost all of the students in our sample who requested dormitories 3, 4, 5, 6, and 7 as their first choice ended up in those dormitories. Because random assignment to a dormitory occurred only for students who requested dormitories 1 and 2, we restricted our sample to students who listed one of these two dormitories as their first choice. Our final sample included 144 males and 244 females.

As a check of the dormitory randomization process, we tested and did not find any statistically significant differences in students' weight and behaviors at baseline among the dormitories. As final, but anecdotal, evidence, we informally interviewed current students on campus who informed us that the "best" dormitories are dormitories 5 and 7. This led us to suspect that incoming students were requesting dormitory 1 and 2 simply because they were the first two dormitories listed (in alphabetical order) on the housing application form; hence, restricting our sample for analysis to these students allowed us to isolate the environment effect on weight or behavior without a reverse causality bias.

\section{Instrument and measures}

We developed our survey instrument using questions similar to those found in other health surveys that endeavor to ascertain weight and height without actual measurement ${ }^{28,29}$. The final instrument contained 39 questions and took approximately 5-7 minutes to complete. We administered our survey online.

Our main measures of interest were weight and the following eating and exercise behaviors: frequency of exercise per week, and typical number of meals and snacks consumed per day. To create an exercise frequency measure, we first asked students whether they exercised and then, "over the past year, how many times per week did you go to the gym?" and "over the past year, how many times did you exercise outside of the gym?" To assess the number of meals and snacks, we asked students, "over the past year, how many meals per day did you typically eat?" and separately, "over the past year, how many snacks per day did you typically eat?" We calculated the walking distance (in miles) of each dormitory from the closest campus gym permission has been granted for this version to appear in e-Publications@Marquette. [Publisher] does not grant permission for this article to be further copied/distributed or hosted elsewhere without the express permission from [Publisher].] 
and the center of campus (student library and study center) and ascertained the presence of an on-site dining hall from the ORL website.

\section{Statistical methods}

Because of documented gender differences in weight perceptions and behaviors ${ }^{30,31}$, we conducted our analysis separately for males and females. For Aim 1, we tested whether behaviors during the freshman year and weight at the end of the freshman year varied across campus dormitories by regressing the weight and behavior variables on a set of dormitory fixed effects. For Aim 2, we examined whether the differences in weight and behaviors could be linked to specific dormitory attributes (presence of on-site dining, proximity to the gym, and proximity to central campus), by regressing the weight and behavior variables on the dormitory characteristics. We adjusted for baseline values of the dependent variable in all models and included height (in centimeters) as a control variable in all models in which weight was the dependent variable. We clustered all standard errors at the dormitory level to address the multi-level nature of these data (i.e., to deal with the intraclass correlation within dormitories). Although we only analyzed students randomly assigned to dormitories, we also included a vector of indicators for each student's first, second, third, and fourth dormitory choices, thereby fully adjusting for each student's dormitory preferences. We also estimated the models using the body mass index instead of weight and found findings similar to those reported here (available upon request) ${ }^{32}$.

\section{Results}

The average age of students was 18.1 and 18.2 for males and females, respectively, and $91 \%$ of both males and females were Caucasian. Females were much more likely to live in a dormitory with an on-site dining hall (77\%) as compared to males (31\%), and lived closer, on average, to campus gyms (.17 vs. .21 miles) and to central campus (.24 vs. .30 miles). Table 1 shows that on average, the students in our sample weighed more at the time of the second survey, with female students having gained more weight on average than male students ( $1.23 \mathrm{vs} . .66 \mathrm{~kg}$ ). Although male students reported 
exercising more frequently on average, both males and females reported exercising less frequently during the freshman year as compared to the year before college entry. Both the number of meals and snacks typically consumed per day also decreased compared to the previous year.

For Aim 1, we found that dormitory assignment significantly influenced students' weight gain and behaviors during the freshman year (Table 2). We consistently found strong dormitory fixed effects for both males and females in our sample: the F-statistics for joint significance of these fixed effects are significant at better than the $1 \%$ level for both weight and behaviors. The omitted dormitory in these regressions is dormitory 5 , the centrally located hall with an on-site dining facility. Male students assigned to dormitories 2 and 6 and females assigned to dormitories 2 and 4 weighed significantly less than other students in the spring. We also found that females in dormitories 2 and 7 exercised more frequently during the freshman year.

Dormitory 7 houses one of the campus gyms and dormitory 2 is only .13 miles from dormitory 7. Despite exercising more frequently, only females assigned to dormitory 2 weighed significantly less in the spring. However, this may be because dormitory 7 has an on-site dining hall.

Table 2. Dormitory fixed effects on weight and behaviors ${ }^{a, b}$

\section{Dependent variables (measured at follow-up)}

Weight (kg) $\begin{gathered}\text { Exercise } \\ \text { frequency }\end{gathered}$ Meals/day Snacks/day

Males

\begin{tabular}{|c|c|c|c|c|}
\hline Dormitory 1 & $-.81(-1.99, .38)$ & $-.97(-2.56, .62)$ & $-.29(-.82, .23)$ & $-.32(-.48,-.06)^{*}$ \\
\hline Dormitory 2 & $-.62(-2.84,-1.60)$ & $-.21(-.50, .09)$ & $-.21(-.43,0)$ & $-.40(-.67,-.13)^{*}$ \\
\hline Dormitory 4 & $-2.40(-5.59, .80)$ & $.81(-.65,2.28)$ & $.08(-.28, .44)$ & $-.12(-.67,-.43)$ \\
\hline Dormitory 6 & $-.87(-1.66,-.08)^{*}$ & $-.58(-1.37,-.20)$ & $-.04(-.22, .15)$ & $-.54(-.90,-.19)^{*}$ \\
\hline Observations & 142 & 144 & 113 & 111 \\
\hline \multicolumn{5}{|l|}{ Females } \\
\hline Dormitory 1 & $.02(-.83, .88)$ & $-.17(-.88, .54)$ & $-.02(-.44, .40)$ & $.57(.18, .96)^{*}$ \\
\hline Dormitory 2 & $-1.09(-1.46,-.72)^{* *}$ & $2.18(1.82,2.54)^{* *}$ & $-.07(-.29, .14)$ & $-.05(-.21, .31)$ \\
\hline Dormitory 3 & $.32(-.12, .77)$ & $.06(-.35, .47)$ & $.08(-.06, .22)$ & $.36(.22, .51)^{* *}$ \\
\hline Dormitory 4 & $-1.90(-3.25,-.54)^{*}$ & $.55(-.53,1.63)$ & $.26(.08, .45)^{*}$ & $.01(-.35, .38)$ \\
\hline Dormitory 7 & $.13(-1.47,1.74)$ & $3.23(2.38,4.07)^{* *}$ & $.14(-.65, .93)$ & $.07(-.3, .44)$ \\
\hline Observation & 244 & 244 & 208 & 203 \\
\hline
\end{tabular}

[Citation: Journal/Monograph Title, Vol. XX, No. X (yyyy): pg. XX-XX. DOI. This article is @ [Publisher's Name] and permission has been granted for this version to appear in e-Publications@Marquette. [Publisher] does not grant permission for this article to be further copied/distributed or hosted elsewhere without the express permission from [Publisher].] 
Note: Reference dormitory is dormitory 5, centrally located with on-site dining. Coefficients and 95\% confidence intervals (in parentheses). Note that 2 males are missing values for height and 31 and 33 males are missing values for meals and snacks per day, respectively; similarly, 36 and 41 females are missing values for meals and snacks per day, respectively.

$* p<.05$.

$* * p<.01$.

a Each model adjusts for dormitory preferences of the student and measures of the dependent variable at baseline. In models where weight is the dependent variable, we also control for the student's height.

b In each model (column), the dependent variable is measured at follow-up and we control for the baseline measure of the dependent variable.

Table 3 shows the results of our analysis for Aim 2. Overall, the presence of an on-site dining hall and proximity to a campus gym and to central campus did not explain significantly the variance in weight for male students. However, we found that females who lived in a dormitory with an on-site dining hall weighed $.85 \mathrm{~kg}(p=.03)$ more in the spring than those who lived in a dormitory without a dining hall. Furthermore, we found strong behavioral effects of the on-site dining hall for both males and females. Males who lived in dormitories with a dining hall reported eating more meals and snacks per day $(.22[p$ $=.02]$ and $.38[p=.01]$, respectively) in the Spring than males otherwise assigned. Females who lived in dormitories with on-site dining reported exercising $1.43(p=.002)$ fewer times per week on average in the Spring than females who lived in a dormitory without a dining hall.

Table 3. Physical environment effects on weight and behaviors ${ }^{a}$

Dependent variables (measured at follow-up)

\begin{tabular}{|c|c|c|c|c|}
\hline & Weight (kg) & Exercise frequency & Meals/day & Snacks/day \\
\hline \multicolumn{5}{|l|}{ Males } \\
\hline $\begin{array}{l}\text { On-site } \\
\text { dining hall }\end{array}$ & $.19(-2.37,2.76)$ & $.49(-.11,1.09)$ & $.22(.06, .37)^{*}$ & $.38(.18, .58)^{* *}$ \\
\hline $\begin{array}{l}\text { Distance to } \\
\text { gym }\end{array}$ & $-.25(-1.37, .87)$ & $-.22(-.81, .38)$ & $-.003(-.22, .21)$ & $.003(-.12, .13)$ \\
\hline $\begin{array}{l}\text { Distance to } \\
\text { central } \\
\text { campus }\end{array}$ & $-.08(-.80, .63)$ & $.16(-.21, .54)$ & $.08(-.07, .23)$ & $-.07(-.56, .42)$ \\
\hline Observations & 142 & 144 & 113 & 111 \\
\hline \multicolumn{5}{|l|}{ Females } \\
\hline $\begin{array}{l}\text { On-site } \\
\text { dining hall }\end{array}$ & $.85(.12,1.57)^{*}$ & $-1.43(-2.03,-.83)^{* *}$ & $.09(-.25, .44)$ & $.01(-.16, .18)$ \\
\hline $\begin{array}{l}\text { Distance to } \\
\text { gym }\end{array}$ & $.13(-.32, .59)$ & $-.54(-1.02,-.06)^{*}$ & $.05(-.01, .11)$ & $.23(.04, .42)^{*}$ \\
\hline
\end{tabular}

[Citation: Journal/Monograph Title, Vol. XX, No. X (yyyy): pg. XX-XX. DOI. This article is @ [Publisher's Name] and permission has been granted for this version to appear in e-Publications@Marquette. [Publisher] does not grant permission for this article to be further copied/distributed or hosted elsewhere without the express permission from [Publisher].] 
NOT THE PUBLISHED VERSION; this is the author's final, peer-reviewed manuscript. The published version may be accessed by following the link in the citation at the bottom of the page.

Dependent variables (measured at follow-up)

$\begin{array}{llll}\begin{array}{l}\text { Distance to } \\ \text { central } \\ \text { campus }\end{array} & -.45(-1.15, .25) .97(.30,1.64)^{*} & .07(-.08, .22) & -.01(-.31,-.28) \\ \text { Observations } 244 & 244 & 208 & 203\end{array}$

Note: Coefficients and 95\% confidence intervals (in parentheses). Distance to gym and distance to central campus have been standardized. Note that 2 males are missing values for height and 31 and 33 males are missing values for meals and snacks per day, respectively; similarly, 36 and 41 females are missing values for meals and snacks per day, respectively.

$* p<.05$.

$* * p<.01$.

a Each model adjusts for dormitory preferences of the student and measures of the dependent variable at baseline. In models where weight is the dependent variable, we also control for the student's height.

Our results also provide some evidence of the effect of proximity to campus gyms and central campus. Note that all distance variables have been standardized in the regressions in Table 3 for ease of interpretation. Proximity to campus gyms and central campus had opposite effects for female exercise behavior. Females who lived farther from campus gyms reported exercising less $(.54[p=.03])$, but females who lived farther from central campus reported greater exercise per week $(.97[p=.01])$, thus implying two distinct effects of living far from central campus (thus having to walk more to classrooms and other campus facilities, and to social activities) and living far from campus gyms.

\section{Discussion}

The objective of this work was to examine the causal effect of physical environment on weight-related behaviors and weight gain. Because of randomized assignment, physically active students were not more likely to live in dormitories with an on-site dining hall or a nearby gym than were students who preferred a sedentary lifestyle. Similarly, the university did not locate campus gyms or dining halls on the basis of the preferences of dormitory residents regarding exercise or food. Thus, we were able to get an unbiased estimate of the causal effect of physical environment on behaviors and weight without reverse causality bias. 
NOT THE PUBLISHED VERSION; this is the author's final, peer-reviewed manuscript. The published version may be accessed by following the link in the citation at the bottom of the page.

We showed that both weight gain and related behaviors vary across campus dormitories. This is consistent with previous research, but our measures of physical environment are plausibly more exogenous than in previous cross-sectional studies. In other words, by investigating the effect of randomly assigned physical environment characteristics, our estimates are not biased by the likelihood that in most settings, individuals choose where to live and work. Dormitory fixed effects are often independently and always jointly significant in predicting changes in behaviors and weight.

We found consistent evidence of the effect of an on-site dining hall for female students. Female students randomly assigned to dormitories with an on-site dining hall weighed more and exercised less during the freshman year as compared with females otherwise assigned. For male students, living in a dormitory with an on-site dining hall resulted in significantly more frequent meals and snacks. These are novel findings, as food environment has not been previously linked to weight gain or to weight-related behaviors in the higher educational institution setting. These results are consistent with previous evidence (where physical environment was not randomly assigned) of the effects of proximity of fast food restaurants (including buffet-style dining) as well as of the effect of food environment in primary and secondary schools $3,8,9,10,22,33,34$.

Although the behavioral mechanism seems to vary by gender (i.e., females spend less time exercising when food is more readily available, whereas males eat more), disentangling these effects requires more data and investigation as the relationships between access to food, eating, and exercising are likely interdependent. We simply may not be picking up the eating behavior effect for females and the exercising effect for males because of our relatively small sample sizes and this likely interdependence.

We also found that living closer to a gym increased the frequency of exercise for females. The effect on the frequency of exercise is in line with the previous research ${ }^{3,8,9,10}$. Although we did not find evidence that proximity to the gym affected weight gain, this may be at least be partly because of our lack of better anthropometric measurements (e.g., waist circumference or body fat percentage). Such measures would allow us to distinguish between increased permission has been granted for this version to appear in e-Publications@Marquette. [Publisher] does not grant permission for this article to be further copied/distributed or hosted elsewhere without the express permission from [Publisher].] 
muscle mass and increased fat deposits, both of which are conceivable outcomes as a result of developmentally appropriate growth and these environmental factors.

Finally, the distance to central campus was associated with significantly more exercise for female students, likely because of more walking to access academic buildings and student service facilities. Indeed, living .43 miles away from central campus (dormitory four) can easily add up to $>1.5$ miles of walking per day.

We point out that the finding of environmental influences on behaviors is of great practical importance regardless of whether the behaviors are accompanied by significant changes in body weight. Unveiling environmental factors that affect weight-related behaviors in young adults can help educational administrators and public policy officials optimize the campus environment to best meet the current needs of the students, as well as gently "nudge" students to set the pace for life-long adoption of healthy lifestyles ${ }^{34}$.

Although the results of our study do not suffer from many of the problems of previous endeavors to study physical environment influences on weight status, we point out the following caveats. The first limitation of our study is one that is common to many environmental influence studies: the results may be overstating or understating the importance of the examined environmental influences because of potential confounding from unobserved environmental attributes not controlled for in the study. Furthermore, we should note that although we establish convincing evidence on the link between physical environment and weight and related behaviors for this particular population, we are unable to say anything about the role of the social environment, which likely interacts with these important physical environment characteristics. Second, students self-reported all of our measures of weight, height, and behaviors. This may be problematic for measurement of weight and weight change, because other studies have found that, in general, individuals tend to understate their weight ${ }^{35}$, and because our baseline survey is phrased to elicit information about "the past year" as a whole whereas behaviors during the summer before college entry can be different from those during the senior year of high school. However, the attenuation bias from measurement error implies that our effect sizes

[Citation: Journal/Monograph Title, Vol. XX, No. X (yyyy): pg. XX-XX. DOI. This article is @ [Publisher's Name] and permission has been granted for this version to appear in e-Publications@ Marquette. [Publisher] does not grant permission for this article to be further copied/distributed or hosted elsewhere without the express permission from [Publisher].] 
may be conservative, especially as models with fixed effects exacerbate this attenuation bias. A third limitation of our study is that we are unable to account for developmentally appropriate changes in weight or distinguish between the sources of the weight gain. Ideally, we would have other relevant measures, such as waist circumference or percent body fat. Finally, although our results are consistent with previous cross-sectional studies that have focused on larger adult and/or adolescent samples $36,37,38$, we caution against generalizing our findings to other populations.

\section{Acknowledgments}

The authors thank seminar participants at Marquette University, University of Michigan, and the University of Wisconsin-Milwaukee. This study was funded by a research grant from. At the time of participation, informed consent was obtained. The Marquette University institutional review board approved all analyses contained herein.

\section{References}

${ }^{1}$ E. Cohen-Cole, J.M. Fletcher. Is obesity contagious?: Social networks vs. environmental factors in the obesity epidemic J Health Econ, 27 (2008), pp. 1382-1387

2 N.A. Christakis, J.H. Fowler. The spread of obesity in a large social network over 32 years. N Engl J Med, 357 (2007), pp. 370-379

3 M.A. Papas, A.J. Alberg, R. Ewing, et al. The built environment and obesity. Epidemiol Rev, 29 (2007), pp. 129-143

${ }^{4} \mathrm{~K}$. Morland, S. Wing, A.D. Roux. The contextual effect of the local food environment on residents' diets: The atherosclerosis risk in communities study. Am J Public Health, 92 (2002), pp. 1761-1768

${ }^{5}$ L.D. Frank, M.A. Andresen, T.L. Schmid. Obesity relationships with community design, physical activity, and time spent in cars. Am J Prev Med, 27 (2004), pp. 87-96

${ }^{6}$ R.C. Brownson, E.A. Baker, R.A. Housemann, et al. Environmental and policy determinants of physical activity in the United States. Am J Public Health, 91 (2001), pp. 1995-2003

7 R. Ewing, R.C. Brownson, D. Berrigan. Relationship between urban sprawl and weight of United States youth. Am J Prev Med, 31 (2006), pp. 464-474 ${ }^{8}$ A.A. Casey, M. Elliott, K. Glanz, et al. Impact of the food environment and physical activity environment on behaviors and weight status in rural U.S. communities. Prev Med, 47 (2008), pp. 600-604 
NOT THE PUBLISHED VERSION; this is the author's final, peer-reviewed manuscript. The published version may be accessed by following the link in the citation at the bottom of the page.

9 S. Inagami, D. Cohen, A. Brown, et al. Body mass index, neighborhood fast food and restaurant concentration, and car ownership. J Urban Health, 86 (2009), pp. 683-695

${ }^{10}$ B. Saelens, J. Sallis, L. Frank. Environmental correlates of walking and cycling: Findings from the transportation, urban design, and planning literatures. Ann Behav Med, 25 (2003), pp. 80-91

${ }^{11}$ Centers for Disease Control and Prevention (CDC). National Center for Health Statistics (NCHS). National Health and Nutrition Examination Survey Questionnaire III. (1988-1994) Services DoHaH: Hyattsville, MD.

${ }^{12}$ Centers for Disease Control and Prevention (CDC). National Center for Health Statistics (NCHS). National Health and Nutrition Examination Survey Questionnaire III. (1999-2004) Services DoHaH: Hyattsville, MD.

13 A.H. Mokdad, B.A. Bowman, E.S. Ford, et al. The continuing epidemics of obesity and diabetes in the United States. J Am Med Assoc, 286 (2001), pp. 1195-1200

14 D.A. Anderson, J.R. Shapiro, J.D. Lundgren. The freshman year of college as a critical period for weight gain: An initial evaluation. Eat Behav, 4 (2003), pp. 363-367

${ }^{15} \mathrm{~S}$. Butler, D. Black, C. Blue, et al. Change in diet, physical activity, and body weight in female college freshmen. Am J Health Behav, 28 (2004), pp. 24-32

${ }^{16}$ L. Hajhosseini, T. Holmes, P. Mohamadi, et al. Changes in Body weight, body composition and resting metabolic rate (RMR) in first-year university freshmen students. J Am Coll Nutr, 25 (2006), pp. 123-127

17 D.J. Hoffman, P. Policastro, V. Quick, et al. Changes in body weight and fat mass of men and women in the first year of college: A study of the "Freshman 15." J Am Coll Health, 55 (2006), pp. 41-45

18 D.A. Levitsky, J. Garay, M. Nausbaum, et al. Monitoring weight daily blocks the freshman weight gain: A model for combating the epidemic of obesity. Int J Obes, 30 (2006), pp. 1003-1010

19 M.L. Morrow, K.C. Heesch, M.K. Dinger, et al. Freshman: 15: Fact or fiction? Obesity, 14 (2006), pp. 1438-1443

20 J.M. Holm-Denoma, T.E. Joiner Jr., K.D. Vohs, T.F. Heatherton. The "freshman fifteen" (the "freshman five" actually): Predictors and possible explanations. Health Psychol, 27 (2008), pp. S3-S9

${ }^{21}$ E.E. Lloyd-Richardson, S. Bailey, J.L. Fava, et al. A prospective study of weight gain during the college freshman and sophomore years. Prev Med, 48 (2009), pp. 256-261

22 M.F. Hovell, C.R. Mewborn, Y. Randle, et al. Risk of excess weight gain in university women: A three-year community controlled analysis. Addict Behav, 10 (1985), pp. 15-28

${ }^{23} \mathrm{~K}$. Truesdale, J. Stevens, C. Lewis, et al. Changes in risk factors for cardiovascular disease by baseline weight status in young adults who

[Citation: Journal/Monograph Title, Vol. XX, No. X (yyyy): pg. XX-XX. DOI. This article is @ [Publisher's Name] and permission has been granted for this version to appear in e-Publications@Marquette. [Publisher] does not grant permission for this article to be further copied/distributed or hosted elsewhere without the express permission from [Publisher].] 
maintain or gain weight over 15 years: The CARDIA study. Int J Obes, 30 (2006), pp. 1397-1407

${ }^{24}$ U.S. Department of Health and Human Services. Healthy people 2010: With understanding and improving health and objectives for improving health. Services USDoHaH, Washington, DC (2000)

25 M.C. Nelson, M. Story, N.I. Larson, D. Neumark-Sztainer, L.A. Lytle. Emerging adulthood and college-age youth: An overlooked age for weightrelated behavior change. Obesity, 16 (2008), pp. 2205-2211

26 J.S. Armstrong, T.S. Overton. Estimating nonresponse bias in mail surveys. J Mark Res, 14 (1977), pp. 396-402

27 J.R. Lindner, T.H. Murphy, G.E. Briers. The handling of nonresponse in agricultural education. J Agric Educ, 42 (2001), p. 233

${ }^{28}$ K.M. Harris, C.T. Halpern, E. Whitsel, et al. The National Longitudinal Study of Adolescent Health: Research. Design (2009)

${ }^{29}$ Centers for Disease Control and Prevention (CDC). National Center for Health Statistics (NCHS). Behavioral Risk Factor Surveillance System Survey Questionnaire. Centers for Disease Control and Prevention (CDC), Atlanta, GA (2008)

${ }^{30}$ V.W. Chang, N.A. Christakis. Self-perception of weight appropriateness in the United States: Am Prev Med, 24 (2003), pp. 332-339

31 J. Croll, D. Neumark-Sztainer, M. Story, M. Ireland. Prevalence and risk and protective factors related to disordered eating behaviors among adolescents: Relationship to gender and ethnicity. J Adolesc Health, 31 (2002), pp. 166175

${ }^{32} \mathrm{~K}$. Wildhalm, K. Schoenegger, C. Huemer, et al. Does the BMI reflect body fat in obese children and adolescents?: A study using the TOBEC method. Int J Obes, 25 (2001), pp. 279-285

33 M.A. Clark, M.K. Fox. Nutritional quality of the diets of US public school children and the role of the school meal programs. J Am Diet Assoc, 109 (2 Suppl) (2009), pp. S44-S56

${ }^{34}$ A.M. Snelling, C. Korba, A. Burkey. The National school lunch and competitive food offerings and purchasing behaviors of high school students. J Sch Health, 77 (2007), pp. 701-705

35 M.L. Rowland. Self-reported weight and height. Am J Clin Nutr, 52 (1990), pp. $1125-1133$

36 M.D. Kipke, E. Iverson, D. Moore, et al. Food and park environments: Neighborhood-level risks for childhood obesity in East Los Angeles. J Adolesc Health, 40 (2007), pp. 325-333

37 J.F. Bell, J.S. Wilson, G.C. Liu. Neighborhood greenness and 2-year changes in body mass index of children and youth. Am J Prev Med, 35 (2008), pp. 547-553

[Citation: Journal/Monograph Title, Vol. XX, No. X (yyyy): pg. XX-XX. DOI. This article is @ [Publisher's Name] and permission has been granted for this version to appear in e-Publications@Marquette. [Publisher] does not grant permission for this article to be further copied/distributed or hosted elsewhere without the express permission from [Publisher].] 
NOT THE PUBLISHED VERSION; this is the author's final, peer-reviewed manuscript. The published version may be accessed by following the link in the citation at the bottom of the page.

${ }^{38}$ L.P. Franzini, M.P. Elliott, P.P. Cuccaro, et al. Influences of physical and social neighborhood environments on children's physical activity and obesity. Am J Public Health, 99 (2009), p. 271

\section{About the Authors}

Address correspondence to: Kandice A. Kapinos, Ph.D., Institute for Social

Research, University of Michigan, 426 Thompson Street, Ann Arbor, MI 48104

[Citation: Journal/Monograph Title, Vol. XX, No. X (yyyy): pg. XX-XX. DOI. This article is @ [Publisher's Name] and permission has been granted for this version to appear in e-Publications@Marquette. [Publisher] does not grant permission for this article to be further copied/distributed or hosted elsewhere without the express permission from [Publisher].] 